\title{
STRATEGI PENINGKATAN KEMANDIRIAN ANAK USIA DINI DI TK. DHARMA WANITA BRUMBUNG 1 KEDIRI
}

\author{
Dina Mei Puspitasari \\ Elok Halimatus Sa'diyah \\ Fakultas Psikologi \\ Universitas Islam Negeri (UIN)Maulana Malik Ibrahim Malang \\ Jl. Gajayana 50 Malang Telp. 0341-558916
}

\begin{abstract}
The development of one's independence toward perfection becomes very important to be pursued since the early, more serious, systematic and programmed. As has been trying to do by the teacher in kindergarten. Dharma Wanita Brumbung I in order to increase the independence of children. Researchers interested in conducting research on the theme "Independence Strategy Increase Of Early Childhood In Kindergarten Dharma Wanita Brumbung I ".The research approach is qualitative. Techniques of data collection in this study is by interview, observation and documentation. Data analysis : data reduction, data presentation, drawing conclusions and verification of data. Subjects : 4 Women Brumbung I TK.Dharma teachers, where teachers who hold full responsibility for the child, while the child is in school. The results showed that strategy pursued in kindergarten teachers includes: provide positive self-understanding early childhood, which gives confidece and responsibility to the child.
\end{abstract}

Keyword : Kemandirian, Anak Usia Dini

PSIKOISLAMIKA. Jurnal Psikologi Islam (JPI) copyright @ 2014 Laboratorium Penelitian, Kajian Psikologi Islam dan Penerbitan. Volume 11. Nomor 1, Tahun 2014

\section{PENDAHULUAN}

Manusia akan selalu dihadapkan pada situasi dan dinamika kehidupan yang terus berubah dan berkembang. Terlebih lagi ditunjang oleh laju perkembangan teknologi dan arus gelombang kehidupan global yang sulit atau tidak mungkin untuk dibendung.Sehingga tata nilai yang sudah mapan banyak diguncang oleh nilai - nilai baru yang belum tentu positif bagi kehidupan. Ketidakmandirian dan ketergantungan disiplin pada kontrol luar dan bukan dari niat sendiri yang ikhlas akan menghambat etos kerja dan etos kehidupan yang mapan (kompasiana. com, diakses pada tanggal 10/05/2014).

Problem di atas semakin meresahkan jika dikaitkan dengan situasi masa depan yang diperkirakan akan semakin kompleks dan penuh tantangan. Dan tantangan itu memberikan dua alternatif, yaitu pasrah pada nasib atau mempersiapkan diri sebaik mungkin. Oleh karena itu perkembangan kemandirian seseorang menuju ke arah kesempurnaan menjadi sangat penting untuk diupayakan lebih serius, sistematis dan terprogram.

Salah satu hak dasar anak adalah hak untuk tumbuh dan berkembang.Artinya anak memperoleh kesempatan seluas-luasnya untuk tumbuh secara fisik dan berkembang secara psikologis. Ini semua akan terjadi bila lingkungan sangat kondusif sehingga memungkinkan perkembangan jiwa mereka dapat terlaksana dengan optimal (Seto Mulyadi dalam Dariyo, 2007:v).

Pada usia dua sampai tiga tahun adalah masa usia prasekolah. Menurut Lichtensein \& Ireton (1984) ada 7 (tujuh) persyaratan yang harus dipenuhi oleh seorang anak agar berhasil dalam mengikuti pendidikan prasekolah, antara lain : (1) kemampuan kognitif yang memadai,(2) ketrampilan berbahasa lisan dan ketrampilan menulis, (3) artikulasi bahasa yang jelas dan dipahami oleh orang lain, (4) memiliki ketrampilan motorik yang memadai, 
(5) mampu menolong diri sendiri dengan baik, (6) memiliki ketrampilan psikososial yang memadai, (7) kemampuan proses persepsi dan integrative. Salah satu dari persyaratan di atas adalah memiliki ketrampilan menolong diri sendiri yang artinya adalah anak diharapkan mampu bersikap mandiri. Pada anak-anak yang telah diajar dan terlatih dengan baik oleh orang tua dirumah akan dapat melakukan kegiatan yang bertujuan untuk memenuhi kebutuhan diri sendiri dinamakan (self-help skill), sedangkan anak-anak yang tidak dilatih dengan baik oleh orang tua dirumah belum tentu dapat melakukan kegiatan yang bertujuan untuk memenuhi kebutuhan diri sendiri. Dengan menguasai ketrampilan ini maka seorang anak tidak akan merepotkan orang lain. Kemampuan menolong diri sendiri ini antara lain: memakai baju, sepatu, sandal, menggosok gigi, mandi, menyisir rambut, makan atau minum sendiri. Berbagai ketrampilan tersebut sangat penting bagi seorang anak ketika dia sudah memasuki pendidikan prasekolah (Dariyo,2007:169-172).

Selain perlu disayangi dan dilindungi, anak usia dini juga perlu dihargai, anak akan merasa dihargai jika ia boleh ikut berperan aktif dalam kegiatan keluarga sehari-hari seperti ikut memasak, mencuci mobil, membersihkan meja dan sebagainya. Namun sebagian orang tua, cenderung melarang anak intuk ikut dalam kegiatan dirumah, karena ingin pekerjaan cepat selesai (Shoba, 2006:21). Padahal, orang tua memiliki peranan yang amat penting dalam upaya mendukung perkembangan anak khususnya saat mereka berada pada tahapan usia dini. Hal di atas membuktikan bahwa pentingnya untuk para orang tua dan guru untuk menumbuhkan sikap mandiri pada anak, tentunya dengan menggunakan strategi yang tepat dan sesuai, agar salah satu tugas utama perkembangan ini dapat terwujud yaitu kemandirian.

Kesimpulan yang dapat diambil dari penjelasan di atas, Tujuan orang tua memberi kepercayaan dan tanggung jawab untuk melakukan aktivitas tanpa bantuan orang lain, karena anak-anak yang memperoleh kesempatan tersebut akan menjadi anak mampu mandiri dalam menjalani kegiatan sehari-hari, karena anak-anak yang memperoleh kesempatan dan tanggung jawab dari orang tua akan tumbuh menjadi anak yang berinisiatif, sosiabel, adaptif, berani, percaya diri optimis dan kreatif. Hal-hal yang telah disebutkan di atas melatar belakangi pemikiran peneliti bahwa betapa pentingnya menumbuh kembangkan sikap kemandirian pada diri anak sejak usia dini, namun hal ini disesuaikan dengan dorongan sendiri (motivasi), kompetensi, inisiatif dan kreativitas dari anak tersebut.

Pada masa kanak-kanak adalah masa-masa bermain dan bersenang-senang, jadi untuk menumbuh kembangkan kemandirian anak tidak perlu dipaksakan, dan harus menggunakan strategi yang sesuai. Dalam upaya pembinaan terhadap pendidikan anak usia dini tersebut diperlukannya sebuah upaya dan strategi dalam peningkatan kemandiriannya.

Bagi orang tua maupun guru pasti lah tidak mudah meningkatkan tugas perkembangan yang satu ini yaitu kemandirian, karena pada usia dini adalah masa-masa bermain dan tidak seharusnya dituntut untuk mandiri. Peneliti mengangkat permasalah tersebut untuk diteliti di TK. Dharma Wanita Brumbung I, dengan judul Strategi Peningkatan Kemandirian Anak Usia dini di TK. Dharma Wanita Brumbung I, Kecamatan Kepung, Kabupaten Kediri. Kemandirian dalam penelitian ini adalah kemampuan seorang anak dalam menyelesaikan segala kegiatan seharihari di sekolah, berdasarkan kemampuan sendiri dilihat dari aspek afektif, kognitif dan psikomotor, sesuai dengan indikator usia anak tersebut, yaitu 4-6 tahun.

\section{KERANGKA KERJA TEORITIK}

Istilah strategi berasal dari kata benda strategos, merupakan gabungan kata stratus (militer) dengan ago (memimpin).Sebagai kata kerja, stratego berarti merencanakan (to plan). Dalam kamus The American Herritage Dictionary (1976:1273) dikemukakan bahwa "Strategy is the science or art of military command as applied to evarall planning and conduct of large-scale combat operations" selanjutnya dikemukakan pula bahwa strategi adalah the art or skill of using stratagems (a military manouver) designed to deceive or surprise an enemy in politic, bussines, countership, or the like". Pada awalnya strategi berarti kegiatan memimpin militer dalam menjalankan tugas-tugas di lapangan.Konsep strategi yang semula diterapkan dalam kemiliteran dan dunia politik (Bracker, 1980), kemudian banyak diterapkan pula dalam bidang manajemen, dunia usaha, pengadilan dan pendidikan.

Dengan semakin luasnya penerapan strategi, Mintberg dan Waters (1983) mengemukakan bahwa strategi adalah pola umum tentang keputusan atau tindakan (strategies are realized as pattern in streams of decisions or actions). Hardy, Langely dan Rose dalam Sudjana (1986) mengemukakan "strategy is perceived as a plan or a set of explient intention preseeding and controlling action" (strategi dipahami 
dengan rencana atau kehendak yang mendahului dan mengendalikan kegiatan). Berdasarkan pada beberapa pengertian diatas dapat dikemukakan bahwa strategi adalah suatu pola yang direncanakan dan ditetapkan secara sengaja untuk melakukan kegiatan atau tindakan. Strategi mencakup tujuan kegiatan, siapa yang terlibat dalam kegiatan, isi kegiatan, proses kegiatan, dan sarana penunjang kegiatan.

Dalam dunia pendidikan, strategi diartikan sebagai a plan, method or series of activities designed to achieves a particular educational goal (J.R David, 1976). Jadi, dengan demikian strategi dapat diartikan sebagai perencanaan yang berisi tentang rangkaian kegiatan yang di desain untuk mencapai tujuan pendidikan tertentu (Wina Sanjaya, 2006:126).

Strategi adalah suatu rencana yang diutamakan untuk mencapai tujuan, sedangkan taktik adalah langkah-langkah tertentu yang di tempuh untuk melaksanakan strategi.Strategi dikembangkan untuk memenangkan tujuan, dan taktik dikembangkan untuk memenangkan strategi. Strategi dan taktik yang dikembangkan harus memberikan kemudahan bagi subyek untuk melakukan eksplorasi dan penemuan diri, serta mencapai proses dan hasil-hasil yang bermakna (Ridwan, 2004:187).

Berdasarkan beberapa pengertian diatas, maka dapat disimpulkan bahwa strategi adalah suatu pola yang direncanakan dan ditetapkan secara sengaja untuk melakukan kegiatan atau tindakan. Strategi mencakup tujuan, siapa yang terlibat, isi, proses dan sarana penunjang. Kemandirian merupakan kemampuan seseorang untuk bertanggung jawab atas apa yang dilakukannya tanpa membebani orang lain (Wiyani,2013:89).

Kata kemandirian berasal dari kata dasar diri yang mendapakan awalan "ke" dan akhiran an yang kemudian membentuk suatu kata keadaan atau kata benda. Karena kemandirian berasal dari kata dasar diri, pembahasan mengenai kemandirian tidak dapat dilepaskan dari pembahasan mengenai perkembangan diri itu sendiri, yang dalam konsep Carl Rogers disebut dengan istilah self oleh Brammer dan Shostrom(1982) karena diri merupakan inti dari kemandirian (dalam Ali, 2006, hlm:109).

Kemandirian (self-reliance) adalah kemampuan untuk mengelola semua yang dimilikinya sendiri yaitu mengetahui bagaimana mengelola waktu, berjalan, berfikir, secara mandiri, disertai dengan kemampuan dalam mengambil resiko dan memecahkan masalah. Dengan kemnadirian tidak ada kebutuhan untuk mendapatkan persetujuan orang lain ketika hendak melangkah menentukan suatu yang baru. Individu yang mandiri tidak dibutuhkan yang detail dan terus menerus tentang bagaimana mencapai produk akhir, ia bisa berstandar pada diri sendiri. Kemandirian berkenaan dengan pribadi yang mandiri, kreatif dan mampu berdiri sendiri yaitu memiliki kepercayaan diri yang bisa membuat seseorang mampu sebagai individu untuk beradaptasi dan mengurus segala hal dengan dirinya sendiri (Parker, 2006, hlm: 226-227).

Dari berbagai pendapat diatas maka dapat disimpulkan bahwa kemandirian adalah keadaan seseorang dimana ia berusaha melakukan semua hal dengan kemampuannya sendiri, tanpa bantuan dari orang lain. Kemandirian juga berarti ketrampilan menolong diri sendiri untuk melakukan suatu hal tanpa bergantung pada orang lain.

Kemandirian anak usia dini dalam melakukan prosedur-prosedur ketrampilan merupakan kemampuan untuk melakukan aktivitas sederhana sehari-hari, seperti makan tanpa arus di suapi, mampu memakai kaos kaki dan baju sendiri, bisa buang air kecil / air besar sendiri, mampu memakai baju dan celana sendiri, dan dapat memilih mana bekal yang harus dibawa nya saat belajar di KB maupun TK serta dapat merapikan mainannya sendiri. Sementara kemandirian anak usia dini dalam bergaul terwujud pada kemampuan mereka dalam memili teman, keberanian mereka belajar dikelas tanpa di temani orang tua, dan mau berbagi bekal/jajan kepada temannya saat bermain (Wiyani, 2013:31).

Tak dapat dipungkiri bahwa anak dalam usia dini merupakan anak yang masih sangat muda. Walaupun demikian, mereka tetap saja membutuhkan kemandirian sebagai kebutuhan fisik meeka. Winnicot mengungkapkan bahwa anak usia dini belajar untuk tumbuh dan berkembang secara cepat dan tak terduga. Anak usia dini akan memperoleh kebiasaan dengan apa mereka bermain, apa yang mereka senangi untuk dimakan, dan kapan waktu mereka tidur. Semua kegiatan tersebut harus mereka pilih dan merupakan kebutuhan fisik mereka. Dari pendapat Winnicot tersebut, sangat dimungkinkan sekali jika anak usia dini dapat memiliki karakter mandiri (Wiyani, 2013:29).

Subroto mengartikan kemandirian sebagai kemampuan anak untuk melakukan aktifitas sendiri dalam berbagai hal. Astiati juga mengartikan kemandirian yang hamper sama dengan Subroto. Menurutnya, kemandirian merupakan kemampuan atau ketrampilan yang dimiliki anak untuk 
melakukan segala sesuatunya sendiri, baik yang terkait dengan aktivitas bantu diri maupun aktivitas kesehariannya tanpa bantuan orang lain (Wiyani, 2013:27-28).

\section{METODE}

Berdasarkan permasalahan dan tujuan penelitian yang telah dikemukakan diatas, peneliti menggunakan metode kualitatif dengan jenis penelitian deskriptif. Penelitian kualitatif deskriptif adalah penelitian yang bermaksud untuk memahami fenomena tentang apa yang dialami oleh subjek penelitian secara holistik, dan dengan cara deskriptif dalam bentuk kata-kata dan bahasa, pada suatu konteks khusus yang alamiah dan dengan memanfaatkan berbagai metode ilmiah (Bungin, 2008:68-69).

Alasan peneliti menggunakan penelitian kualitatif karena ingin memusatkan penelitian pada prinsip-prinsip umum yang mendasari wujud satuan gejala yang ada serta bertujuan memahami situasi sosial, peristiwa, peran, interaksi dan kelompok. Penggunaan pendekatan kualitatif dengan metode pengamatan terlibat dan wawancara sangatlah cocok karena dapat mengasilkan data deskriptif tentang strategi peningkatan kemandirian anak usia dini.

\section{HASIL}

Hasil penelitian yang telah dilakukan oleh peneliti memperlihatkan bahwa :

1. Bentuk kemandirian anak usia dini di TK.Dharma Wanita Brumbung I Kemandirian yang berkembang pada peserta didik di TK. Dharma Wanita Brumbung I mempunyai perbedaan dalam segi aspek-aspeknya. Peserta didik yang dianggap mandiri oleh ibu guru yaitu HA terlihat mandiri dalam aspek sosialnya sedangkan aspek emosional dan intelektual masih perlu pembelajaran lagi.

Selanjutnya DA terlihat mandiri dalam aspek sosialnya, untuk aspek intelektual dan emosionalnya masih memerlukan pembelajaran dan peningkatan. Kemudian peserta didik berikutnya yaitu DS yang terlihat mandiri dilihat dari aspek intelektualnya, untuk aspek emosionalnya juga sudah bagus dan aspek sosialnya masih perlu dilakukan peningkatan lagi. Anak yang dikatakan mandiri tersebut mempunyai ciri-ciri antara lain Percaya diri, kreatif, motivasi intrinsik tinggi, kemampuan bantu diri yang baik, tidak bergantung pada orang lain, bertanggung jawab dan tidak cengeng.
Bagi peserta didik yang dikatakan kurang mandiri oleh ibu guru yaitu RA yang bersikap manja dan berketergantungan berlebihan terhadap orang lain, rendah dalam berbagai aspek aspek kemandiriannya. Selanjutnya FI, kemandiriannya rendah dalam aspek sosial maupun emosionalnya namun tinggi dalam aspek intelektualnya, begitu pula dengan AA. Anak yang dikatakan kurang mandiri mempunyai ciri-ciri sebagai berikut: kurang percaya diri, kurang kreatif, kurangnya motivasi, kemampuan bantu diri yang rendah sehingga membuatnya bergantung pada orang lain, kurangnya rasa tanggung jawab dan cenderung lebih cengeng 2. Strategi yang dilakukan dalam peningkatan kemandirian anak usia dini di TK.Dharma Wanita Brumbung I

Dalam rangka peningkatan kemandirian anak usia dini di TK.Dharma Wanita Brumbung I, para guru menerapkan strategi sebagai berikut :

a) Memberikan pemahaman positif pada diri anak usia dini, yaitu memberikan kepercayaan dan tanggung jawab kepada anak.

b) Mendidik anak usia dini terbiasa bersih dan rapi, menyiapkan penyimpanan, memberi contoh, dan menjelaskan konsekuensi hidup jika tidak rapi dan tidak bersih.

c) Memberikan permainan yang dapat membentuk kemandirian anak usia dini. Permainan terdapat dua jenis yaitu, permainan aktif dan permainan pasif. Permainan aktif adalah, permainan yang berfungsi untuk melatih motorik kasar anak karena lebih mengandalkan aktivitas fisik. Aktivitas yang melibatkan fisik ini tidak bisa sembarangan karena harus dalam pengawasan orang tua atau guru. Sedangkan permainan pasif adalah, berupa permainan yang lebih melibatkan imajinasi anak.

d) Memberi anak usia dini pilihan sesuai minatnya

e) Membiasakan anak usia dini berperilaku sesuai dengan tata krama

f) Memotivasi anak supaya tidak malasmalasan

g) Memberi pujian terhadap hasil yang dicapai anak

h) Mengadakan program parenting

2. Faktor yang mendukung dan menghambat dalam peningkatan kemandirian anak usia dini 


\section{di TK. Dharma Wanita Brumbung I}

Dalam proses peningkatan kemandirian anakusia dini di TK.Dharma Wanita Brumbung I terdapat faktor yang mendukung danmenghambat. Faktor yang mendukung dalam peningkatan kemandirian anak usia dini di TK.Dharma Wanita Brumbung I yaitu faktor yang menyebabkan kelancaran dalam proses terbentuknya kemandirian, sehingga menjadikan strategi yang dilakukan guru dapat berjalan sesuai harapan. Faktor yang mendukung terdapat 2 macam yaitu : Faktor Internal, yang meliputi : sehat jasmani, urutan kelahiran, dan jenis kelamin. Faktor Eksternal, yang meliputi :Lingkungan, rasa cinta kasih sayang dan pola asuh orang tua dalam keluarga. Sedangkan faktor yang menghambat yaitu faktor yang menyebabkan terhambatnya proses terbentuknya kemandirian, sehingga dapat menjadikan strategi yang dilakukan kurang berjalan dengan lancar, yang meliputi, kurangnya kepercayaan diri anak, kurangnya kerjasama yang baik antara guru dan wali murid dalam upaya peningkatan kemandirian, sikap orang tua yang memanjakan dan terlalu banyak melarang.

\section{KESIMPULAN}

Strategi yang dilakukan guru di TK.Dharma Wanita Brumbung I dalam rangka peningkatan

\section{DAFTAR PUSTAKA}

Al-Qur'an dan terjemahannya. 2002. Surabaya: Mahkota

Ali Mohammad, Asrori Mohammad. 2006. Psikologi Remaja Perkembangan Peserta Didik Jakarta: Bumi Aksara

Chaplin. 1996. Kamus Lengkap Psikologi. Jakarta: Rajawali Press

Dariyo, Agus. 2007. Psikologi Perkembangan Anak Usia Tiga Tahun Pertama(PsikologiAtitama). Bandung: Refika Aditama

Dimyanti, Mahmud. 1990. Psikologi Pendidikan Suatu Pendekatan Terapan. Jogjakarta Djaali. 2013. Psikologi Pendidikan.

Gunarsa, S.D. 2012. Dasar dan Teori Perkembangan

Anak.Jakarta : BPK Gunung Mulia Hasan Alwi dkk., Kamus Besar Bahasa Indonesia,Edisi Ketiga . kemandirian, sebenarnya sudah dilakukan dengan baik namun sepertinya kurang berjalan efisien. Hal tersebut disebabkan kurang nya kerjasama antara guru dan wali murid, serta program parenting yang jarang dilakukan. Kerjasama yang baik antara guru dan wali murid ini sangatlah penting, supaya tujuan peningkatan kemandirian anak bisa terwujud sesuai yang di inginkan, dengan harapan anak dapat mandiri di sekolah maupun dirumah.

Guru dan orang tua diharapkan selalu melatih usaha mandiri anak, mula-mula dalam hal menolong kebutuhan anak itu sendiri dalam keperluan sehari-hari. Kemampuan-kemampuan itu semakin ditingkatkan sesuai dengan bertambahnya usia anak. Melalui permainan yang bisa meningkatkan kemandirian anak misalnya bermain peran atau bermain lari estafet dan masih banyak lagi. Untuk selanjutnya betapa pentingnya motivasi yang harus diberikan oleh guru ataupun orang tua kepada anak usia dini agar mereka menjadi anak yang mandiri. Jika semua upaya dan strategi sudah dilakukan, tapi anak tetap tidak bisa mandiri maka guru dan orang tua harus bersabar dan mengintrospeksi diri, mungkin saja disebabkan oleh sikap guru atau orang tua yang kurang peduli. Guru dan orang tua sebagai model yang akan ditirukan oleh anak, maka dari itu guru maupun orang tua harus mampu memberi contoh yang baik terhadap anak.

Jakarta: Balai Pustaka

Hurlock, E.B. 1990. Psikologi Perkembangan Suatu Pendekatan Sepanjang Rentang Kehidupan(Terjemahan). Jakarta: Erlangga.

Monks, dkk. 2006. Psikologi Perkembangan. Pengantar Dalam Berbagai Bagiannya. Yogyakarta: UGM Press

Patilima, Hamid. 2007. Metode Penelitian Kualitatif. Bandung: Alfabeta

Santrock, John W. Life-Span Development Perkembangan Masa Hidup. Jakarta: Erlangga

Sugiyono. 2005. Metode Penelitian Kuantitatif Kualitatif dan R\&D (Bandung:Alfabeta)

Susanto, Ahmad. 2011. Perkembangan Anak Usia Dini.Jakarta : Kencana Prenada Media Group Syaodih, Ernawulan. 2005. Perkembangan Anak Taman Kanak-kanak.UPI

Tri Rahayu, lin dkk. 2004. Observasi dan Wawancara. Malang: Bayumedia 
Undang-undang RI. 2003. Tentang Sistem Pendidikan Nasional.Yogyakarta: Pustaka Widyatama Wiyani, Novan Ardy. 2013. Bina Karakter Anak Usia
Dini. Jogjakarta : Ar-Ruzz Media Yusuf, Syamsu. 2006. Psikologi Perkembangan Anak dan Remaja.Bandung: Remaja Rosdakarya 